\title{
Effect of red beet (Beta vulgaris L.) powder addition on physicochemical and microbial characteristics of tofu
}

\author{
Kyo-Yeon Lee ${ }^{1}$, Ah-Na Kim ${ }^{1}$, M. Shafiur Rahman ${ }^{1}$, Sung-Gil Choi ${ }^{1,2 *}$ \\ ${ }^{1}$ Division of Applied Life Science, Gyeongsang National University, Jinju 52828, Korea \\ ${ }^{2}$ Department of Food Science and Technology (Institute of Agriculture and Life Sciences), Gyeongsang National University, \\ Jinju 52828, Korea
}

\section{레드비트 분말 첨가가 두부의 이화학적 및 미생물학적 특성에 미치는 영향}

\author{
이교연 ${ }^{1} \cdot$ 김아나 $^{1} \cdot$ 샤피어라만 ${ }^{1} \cdot$ 최성길 ${ }^{1,2 *}$ \\ ${ }^{1}$ 경상대학교 응용생명과학부 응용생명과학전공, ${ }^{2}$ 경상대학교 농화학식품공학과(농업생명과학연구원)
}

\begin{abstract}
This study aimed to investigate the enhancing effects of a specified amount of red beet (Beta vulgaris $\mathbf{L}$.) powder on the quality of tofu over existing ones. Thereafter, physicochemical characteristics and microbial safety were compared between tofu prepared addition of red beet powder (RBP) at different concentrations (0.5-2\%) and tofu without RBP. No significant differences in sample yield were observed $(p>0.05)$ and, the brix degree and lightness of tofu significantly decreased with an increase in the RBP concentration $(p<0.05)$. Texture analysis revealed that incorporation of RBP significantly increased the hardness of tofu $(p<0.05)$, while the cohesiveness, springiness, and chewiness were not significantly altered. Furthermore, total phenolic content and antioxidant activity of RBP-incorporated tofu were significantly greater than those of untreated tofu on the DPPH radical scavenging assay, ABTS radical scavenging assay, and ferric reducing antioxidant power assay $(\mathbf{p}<\mathbf{0 . 0 5})$. In the case of microbial safety, RBP-incorporated tofu contained significantly fewer aerobic bacteria and yeast during storage than tofu without RBP $(\mathbf{p}<\mathbf{0 . 0 5})$. These results suggest that RBP incorporation in tofu increasees its functional quality and shelf-life.
\end{abstract}

Key words : tofu, red beet(Beta vulgaris L.), physicochemical characteristics, antioxidant, microbial characteristics

\section{서 론}

명아주과(Chenopodiaceae)에 속하는 레드비트(Beta vulgaris L.)는 동부지중해 연안과 중앙아시아 지역이 원산 지로, 비타민 $\mathrm{A}$, 비타민 B군, 비타민 C 및 미네랄이 풍부하 여 천연항산화물질의 공급원이다(1-4). 주요 생리활성으로 는 소화계 질환, 면역계 질환, 다양한 대사성 질환, 고혈압과 심혈관 질환의 예방·치료에 효과가 뛰어나며, 다량의 철분 과 엽산함량으로 기형아 발생을 줄이는데 도움을 주는 것으

*Corresponding author. E-mail : sgchoi@gnu.ac.kr Phone : 82-10-7143-3100, Fax : 82-55-772-1909

Received 19 July 2019; Revised 02 September 2019; Accepted 05 September 2019.

Copyright (c) The Korean Society of Food Preservation. All rights reserved.
로 보고되고 있다(5,6). 레드비트 천연색소의 주요성분으로 알려진 betalains은 alkaloid의 하나로 페놀성물질 및 안토시 아닌계 화합물로 분류되며, 적색의 betacyanin은 열안정성 과 저장안정성이 높아 건강기능성 식품의 소재로 음료, 피 클, 물김치, 아이스크림, 캔디류, 레토르트 등으로 그 이용 가치가 확대되고 있다(7-11). 또한, $\operatorname{Kim}(12)$ 은 비트의 색소 추출물이 E. coli, $S$. enteritidis, B. substilis, $S$. aureus 균종에 있어 향균효과가 나타났으며, 특히 B. substilis 균주에서는 5-10 $\mathrm{mm}^{2}$ 크기의 강한 항균력을 보였다고 보고하였다.

두부는 콩 가공품 중 하나로 수용성 단백질의 disulfide결 합 및 수소결합 등에 의해 응집되어 침전되거나 $\mathrm{pH}$ 에 의해 등전점 $(\mathrm{pH}$ 4.2-4.6)에서 침전되는 성질을 이용하여 제조한 것으로 결핍되기 쉬운 lysine 등의 필수 아미노산 함량이 높으며, 소화흡수율이 $96 \%$ 로 높은 양질의 단백질 급원 식 품이다(13-15). 또한, 두부의 식물성 단백질은 혈중 콜레스 
테롤, 혈중 지질 지방단백질(LDL) 등의 농도 감소로 동맥경 화와 심장병 예방 효과가 있으며, 식이섬유는 콜레스테롤 배설 촉진, 장 기능에 대한 생리활성효과, 식후 혈당 상승과 인슐린 분비 억제 등의 효과가 있어 기능성 식품으로서 주목을 받고 있다(16,17). 그러나 두부는 수분함량이 $80 \%$ 이상으로 높은 수분함량에 의해 보존성이 떨어지는 단점을 가진다(18). 시판되는 포장 두부는 포장 후 열처리 후 유통 되고 있으며, 포장하지 않은 판두부는 저장기간이 실온에 서 1-2일로 매우 짧다. 계절에 따라 4-10월에는 24시간, 11-3 월은 48 시간, $0-10^{\circ} \mathrm{C}$ 냉장에서는 3 일을 권장하고 있으며 특히, 여름철에는 하루를 넘기지 못할 정도로 저장성이 떨 어져 낮은 상품성을 초래하고 있다 $(19,20)$. 최근에는 두부 의 품질을 고급화하고 저장성을 높이기 위하여 다양한 생리 활성 성분을 함유한 천연 소재(양파, 파래, 함초 등)를 두부 에 첨가하여 기능성 보완 및 기호성 향상을 동시에 추구하 기 위한 연구가 활발히 진행되고 있다(21-25).

본 연구에서는 최근 건강식품으로 주목받고 있는 레드비 트 분말의 첨가량을 달리하여 두부를 제조하고, 이들의 이화학적, 항산화 활성, 관능적 품질 특성 및 저장성에 대해 비교 분석함으로써 고품질 두부식품 개발에 필요한 기초 연구 자료를 제공하고자 하였다.

\section{재료 및 방법}

\section{실험재료}

본 실험에 사용된 비트는 제주도 제주시에서 수확된 아 틀란 품종으로 수확 후, (주) 인그린(Ingreen Co., Ltd., Pocheon, Korea)에서 건조분말로 가공 및 제조한 것을 2019 년 1월에 구입하여 사용하였다. 두부 제조에 사용된 대두는 전라북도 완주군에서 수확된 대원콩 품종으로 수확 후, (주) 늘푸른(Neulpuren Co., Ltd., Icheon, Korea)에서 건조분말가 공 및 제조한 것을 2019년도 1 월에 구입하여 사용하였다. 응고제로는 $\mathrm{MgCl}_{2}$ 를 $\mathrm{NH}$ 마켓(Nonghyup Co., Ltd., Seoul, Korea)에서 구입하여 사용하였다. 연구에 사용된 시약은 Folin-Ciocalteu's phenol reagent, galic acid, 2,2-diphenyl-1picryl-hydrazy(DPPH), butylated hydroxyanisoe equivalent, 2,2'-anizo-bis(3-ethylbenzthiazoline-6-sulfonic-acid)(ABTS), trpydyltriazine(TPTZ)는 Sigma-Aldrich(Sigma chemical Co., St. Louis. MO, USA)에서 구입하였다.

\section{두부 제조, 저장 및 수율}

두부는 Lee 등(26)의 방법에 의해 제조되었다. $100 \mathrm{~g}$ 의 대두분말과 물 $1,800 \mathrm{~mL}$ 를 두부제조기(SoyLove, IOM201B, Ronic Co. Ltd., Paju, Korea)를 이용하여 $90^{\circ}$ C에서 60 분 동안 혼합한 후 면포로 여과하여 비지를 제거하였다. 제조된 두유를 $2,000 \mathrm{~mL}$ 유리비커에 옮기고 $80^{\circ} \mathrm{C}$ 로 냉각시
킨 다음, 두유량 대비 비트 분말을 $0,0.5,1.0,1.5,2.0 \%(\mathrm{w} / \mathrm{w})$ 로 첨가하여 교반하였다. 응고제는 원료대두의 $4 \%$ 농도로 첨가하여 30 분 동안 실온에서 15 분 동안 방치하고 압착 성형틀 $(12 \times 18 \times 8 \mathrm{~cm})$ 에 면포를 깔고 완성된 순두부를 넣고 $14 \mathrm{~g} / \mathrm{cm} 2$ 으로 50 분 동안 압착하여 두부를 성형·제조하였 다. 성형된 두부는 증류수에 30 분간 수침하였으며 경사진 쟁반에서 15 분간 방치하여 두부 표면의 수분을 제거한 후 저장실험을 위하여 일정규격 $(4 \times 3 \times 1.5 \mathrm{~cm})$ 으로 자른 후 polypropylene zipper bag $(14 \times 18 \mathrm{~cm})$ 에 증류수 $200 \mathrm{~mL}$ 로 침지한 후 $30^{\circ} \mathrm{C}$ 에서 10 일간 실험을 진행하였다(27). 수율 $(\mathrm{g}$ $/ 100 \mathrm{~g}$ soyflour)은 두부의 압착 성형 후 무게를 측정하여 사용한 대두 무게 $(100 \mathrm{~g})$ 를 기준으로 계산하였다.

$$
\begin{gathered}
\text { 두부수율 }(\mathrm{g} / 100 \mathrm{~g} \text { soyflour })=\text { 제조된 두부의 무게/두부 } \\
\text { 제조 시 사용한 대두분말의 무게 } \times 100
\end{gathered}
$$

\section{당도 및 색도}

비트 분말 첨가량에 따른 두부의 당도 변화를 살펴보기 위하여 두부 $5 \mathrm{~g}$ 에 $50 \mathrm{~mL}$ 의 증류수를 넣어 균질화하여 Abbe refractometer(ATAGO CO., 501-DS, Tokyo, Japan)를 이용하여 3회 반복 측정하였다.

색도의 경우, 두부를 일정한 크기 $(5 \times 5 \times 1 \mathrm{~cm})$ 로 절단하여 두부 표면을 표준백색판 $(\mathrm{L}=93.6, \mathrm{a}=0.31, \mathrm{~b}=0.32)$ 으로 보정 된 색차계(Minolta Sensing Inc., Chroma Meter CR-400, Osaka, Japan)를 이용하여 L(lightness), a(redness) 및 $\mathrm{b}$ (yellowness)값을 3회 반복 측정하였다.

\section{조직감}

비트 분말 첨가량에 따른 두부의 조직감을 분석하기 위 하여 두부를 일정한 크기 $(2 \times 2 \times 2 \mathrm{~cm})$ 로 절단한 다음 Texture Analyzer(Stable Micro stable system Ltd., TA-XT Express, Surrey, England)를 사용하였다. Probe는 $25 \mathrm{~mm}$ cylinder를 장착하였고, texture profile analysis(TPA) mode에서 pre-test speed와 post-test는 $5.0 \mathrm{~mm} / \mathrm{s}$ 으로 하였으며, 조건당 5 회 반 복 측정한 값을 평균하여 나타내었다. Force time curve로부 터 경도(hardness), 탄력성(springiness), 검성(gumminess), 응 집성(cohesiveness), 부착성(adhesiveness) 및 씹힘성 (chewiness)을 산출하여 평균값을 구하였다.

\section{총 폴리페놀 함량 및 항산화 활성}

비트 분말 첨가량에 따른 두부의 총 폴리페놀 함량 및 항산화 활성을 분석하기 위하여 각 조건의 두부를 액체질소 를 이용하여 급속동결하였고 이를 동결건조하여 분말화하 였다. 건조시료를 $80 \%$ 메탄올로 희석하고 균질기(Wiggen Hauser, D-50, Berlin, Germany)로 10,000 rpm에서 30초간 균질하였다. 이를 Shaker(n-Biotech, NB-303, Inchen, Korea) 를 이용하여 $200 \mathrm{rpm}$ 으로 $4^{\circ} \mathrm{C}$ 에서 2 시간 동안 추출한 후 
여과한 것을 실험에 사용하였다.

총 폴리페놀 함량의 경우 여과액 $1 \mathrm{~mL}$ 와 증류수 $9 \mathrm{~mL}$ 를 혼합하여 $1 \mathrm{~mL}$ 의 Folin \& Ciocalteu's phenol reagent를 첨가 한 후 실온 암실에서 5 분간 방치한다. 그 후 $7 \%$ sodium carbonate $10 \mathrm{~mL}$ 과 증류수 $4 \mathrm{~mL}$ 을 첨가하여 총량을 25 $\mathrm{mL}$ 으로 하였다. 이를 실온 암실에서 2 시간 동안 방치한 다음 분광광도계(Shimadzu Corporation, UV-1800, Kyoto, Japan)를 이용하여 $760 \mathrm{~nm}$ 에서 흡광도를 측정하였으며, 총 폴리페놀 함량은 $\mathrm{g}$ gallic acid equivalent(GAE)/kg dry weight(DW)로 나타내었다(28).

$\mathrm{DPPH}$ (2,2-diphenyl-1-picrylhydrazyl) 라디컬 소거 활성 은 Blois(29)의 방법을 변형하여 실험을 진행하였다. 100 $\mathrm{mL}$ 의 에탄올을 $8 \mathrm{mg}$ 의 $\mathrm{DPPH}$ 를 용해시켜 $\mathrm{DPPH}$ 원액을 제조하였다. 여과액 $0.1 \mathrm{~mL}$ 은 $\mathrm{DPPH}$ 용액(OD:1.000) 0.9 $\mathrm{mL}$ 과 혼합하여 실온 암실에서 30 분간 방치 후 분광광도계 를 이용하여 $517 \mathrm{~nm}$ 에서 흡광도를 측정하였으며, 이를 $\mathrm{g}$ butylated hydroxyanisole equivalent(BHAE) $/ \mathrm{kg}$ DW로 나타 내었다.

2-2'-azino-bis(3-ethylbenzthiazoline-6-sulfonic acid)(ABTS) 라디컬 소거능은 Forroogh 등(30)의 방법을 변형하여 실험을 진행하였다. ABTS 용액은 $7 \mathrm{mM} \mathrm{ABTS}$ diammonium salt와 $2.45 \mathrm{mM}$ potassium persulphate를 혼합 후 실온 암실에서 16시간 동안 방치하여 제조하였다. 여과 액 $20 \mu \mathrm{L}$ 와 ABTS 용액 $980 \mu \mathrm{L}$ 를 혼합 후 실온 암실에서 6분 동안 방치한 후 분광광도계를 이용하여 $734 \mathrm{~nm}$ 에서 흡광도를 측정하였다. ABTS 라디컬 소거능은 $\mathrm{g}$ ascorbic acid equivalent(AAE)/kg DW로 나타내었다.

FRAP(ferric ion reducing antioxidant power) 측정은 Benzie와 Strain(31)의 방법을 변형하여 실험을 진행하였다. 즉 $300 \mathrm{mM}$ sodium acetate buffer( $\mathrm{pH}$ 3.6)와 $40 \mathrm{mM} \mathrm{HCl}$ 로 용해시킨 $10 \mathrm{mM}$ trpydyltriazine(TPTZ), $20 \mathrm{mM} \mathrm{FeCl} \cdot 6 \mathrm{H}_{2} \mathrm{O}$ 을 제조하였고, 이를 각각 $10: 1:: 1(\mathrm{v} / \mathrm{v} / \mathrm{v})$ 비율로 혼합하여 FRAP 용액을 제조하였다. 여과액 $50 \mu \mathrm{L}$ 와 FRAP 용액 $1.5 \mathrm{~mL}$ 를 혼합 후 실온 암실에서 30 분간 방치한 후 분광광 도계를 이용하여 $593 \mathrm{~nm}$ 에서 흡광도를 측정하였다. FRAP 환원력은 $\mathrm{g} \mathrm{Fe}(\mathrm{II}) / \mathrm{kg} \mathrm{DW}$ 로 나타내었다.

\section{미생물 농도}

저장기간에 따른 비트 분말 첨가 두부의 미생물 수 측정 은 stomacher bag에 시료 $1 \mathrm{~g}$ 과 $0.85 \%$ 멸균생리식염수 9 $\mathrm{mL}$ 를 가하여 stomacher를 이용하여 120 초간 균질화한 다음 $0.85 \%$ 멸균생리식염수를 이용하여 단계별로 희석해 시료 를 준비하였다. 단계별 희석액 $1 \mathrm{~mL}$ 을 일반세균은 PetrifilmTM aerobic count plate(3M Company, St. Paul, MN, $\mathrm{USA}$ )를 이용하여 접종한 후 각각 48 시간 동안 $35^{\circ} \mathrm{C}$ 에서 배양 후 30-300개 사이의 집락을 계수하여 확인하였고, 검 출된 미생물 수는 시료 $1 \mathrm{~g}$ 당 $\log$ colony forming unit(log
$\mathrm{CFU} / \mathrm{g}$ )으로 나타내었다. 대장균군은 상기의 방법과 동일 하게 실시한 후 Petrifilm ${ }^{\mathrm{TM}}$ coliform count plate $(3 \mathrm{M}$ Company, St. Paul, $\mathrm{MN}, \mathrm{USA}$ )를 이용하여 24 시간 동안 $35^{\circ} \mathrm{C}$ 에서 배양 후 집락을 계수하여 확인하였다. 효모 및 곰팡이 는 상기의 방법과 동일하게 실시한 후 Petrifilm ${ }^{\mathrm{TM}}$ yeast and mold count plate(3M Company, St. Paul, MN, USA)를 이용 하여 120 시간 동안 $25^{\circ} \mathrm{C}$ 에서 배양 후 집락을 계수하여 확인 하였다.

\section{통계처리}

각 실험결과는 3 번 반복실험의 평균표준편차로 나타내 었고, 통계처리는 Windows용 SAS 9.4 version(SAS Institute Inc, Cary, NC, USA)을 이용하여 $\mathrm{p}<0.05$ 수준에서 분산분석 (analysis of variance)을 실시한 후, Duncan의 다중 범위 검정 법(Duncan's multiple range test)으로 유의성을 검증하였다.

\section{결과 및 고찰}

\section{수 율}

레드비트 분말의 첨가량에 따라 제조한 두부의 수율은 압착.성형 후 무게를 측정하여 사용한 대두 무게를 기준으 로 계산하여 비교하였다(Fig. 1). 그 결과 레드비트 분말의 첨가량 0-1.5\% 첨가구에서는 차이를 보이지 않았으며, 레 드비트 분말의 첨가량 $2 \%$ 첨가구에서는 약간 감소하는 경향을 보였으나 유의적인 차이를 보이지 않았다. 일반적 으로 알려진 대두 $100 \mathrm{~g}$ 으로 얻을 수 있는 두부의 양은 230-250 g이며(32), 두부의 수율은 수분함량뿐만 아니라, 콩의 수용성 단백질 함량과 지방질 함량 및 부재료의 첨가 에 따라 직접적인 관련이 있다고 보고된 바 있다(33). Choi 등(34)은 채소류 첨가는 단백질 결합보다는 오히려 단백질

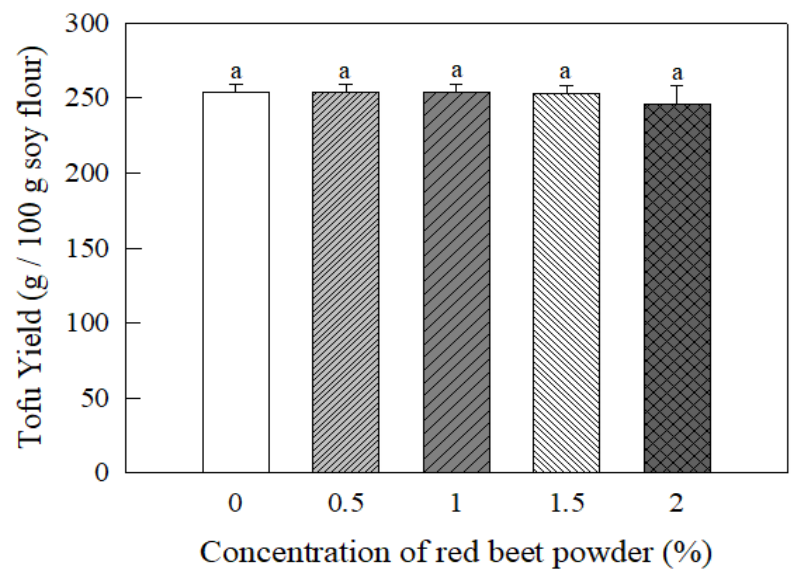

Fig. 1. Yields of tofu added with red beet powder at different concentrations. Differ ent letters indicate significant differences by Duncan's multiple range test $(\mathrm{p}<0.05)$. 
의 결합을 방해하여 첨가농도를 증가시킬수록 수율이 낮아 진다고 보고하였으며, Park (32)은 0, 5, 10, 20\% 마늘을 첨가하여 제조하였을 때, $10 \%$ 이상 첨가부터 감소하는 일 관성 있는 결과를 얻었다고 보고하였다. 천연물의 첨가가 단백질의 응고를 방해하는 것으로 첨가량이 증가할수록 수율이 감소하는 경향을 나타낸다고 보고되고 있다(35).

\section{당도 및 색도}

레드비트 분말의 첨가량에 따른 두부의 당도 및 색도 결과를 Table 1에 나타내었다. 레드비트분말의 첨가량에 따른 당도의 경우 대조군은 $15.00^{\circ} \mathrm{Brix}$ 였고, 비트첨가농도 가 증가함에 따라 전체적으로 $15.33{ }^{\circ} \mathrm{Brix}$ 에서 $17.67^{\circ} \mathrm{Brix}$ 로 증가하는 경향을 나타내었다. Cho와 Choi(5)는 비트분말 을 첨가한 젤리 제조에서 첨가량이 증가할수록 당도가 증가 하는 것으로 나타났으며, 이는 비트에 함유된 당 성분 즉, 여러 가지 다당류, 올리고당, sucrose에 의한 것이라고 보고 하였다.

레드비트 분말의 첨가량에 따른 두부의 색도 측정 결과 $\mathrm{L}$ 값과 $\mathrm{b}$ 값은 첨가량이 증가함에 따라 유의적으로 감소한 반면 a 값의 경우, 유의적으로 증가하는 경향을 나타내었다. $\mathrm{L}$ 값은 대조구가 98.20로 가장 높게 나타났으며, 레드비트 분말 첨가량이 증가할수록 $\mathrm{L}$ 값이 61.37-57.50으로 유의적 으로 감소하는 것으로 나타났다(p<0.05). $\mathrm{a}$ 값의 경우 대조 구가 1.93 으로 가장 낮았고, 레드비트 분말 첨가량이 증가 할수록 a 값이 2.20-5.91으로 증가하는 것으로 나타났다.
이는 안토시아닌계 화합물인 베타시아닌 색소에 의한 것으 로 $\mathrm{L}$ 값의 경우 베타시아닌 색소가 증가함에 따라 빛의 투과가 감소되어 명도가 감소하면서 $\mathrm{L}$ 값이 낮아진 것이며 $\mathrm{a}$ 이 증가한 것으로 보고되고 있다(6). 본 연구와 유사하게 머핀(4)·식빵(37)의 연구결과 모두 레드비트첨가량이 증가 함에 따라 $\mathrm{b}$ 값이 감소하였다고 보고하였다.

\section{조직감}

비트 분말의 첨가량에 따른 두부의 조직감 특성을 측정 한 결과는 Table 2 와 같다. 두부의 Hardness는 대조구와 레드비트 분말 $0.5 \%, 1 \%$ 첨가구에서는 유의적 차이가 없는 것으로 나타났으며, $1.5 \%, 2 \%$ 첨가구의 경우, 각각 406.32 $\mathrm{g}, 412.90 \mathrm{~g}$ 으로 대조구에 비해 유의적으로 낮게 나타났다. Cohesiveness, Springiness 및 Chewiness는 대조구와 첨가구 간의 유의적 차이가 없었다. Gumminess는 대조구와 레드비 트 분말 $0.5 \%, 1 \%$ 첨가구의 경우 유의적 차이가 없는 것으 로 나타났으며, $1.5 \%, 2 \%$ 첨가구의 경우, 각각 $208.46 \mathrm{~g}$, $204.98 \mathrm{~g}$ 으로 유의적으로 감소하는 것으로 나타났다. Kim 등(38)은 기호도가 높은 두부는 견고성이 낮고 부착성이 어느 정도 있는 두부라고 보고하였으며, $\operatorname{Kim}$ 등(39) 해조류 첨가 두부의 조직감 특성에서 해조류 첨가시 대조구에 비하 여 감소하였다고

보고하였다. 또한, 본 연구와 유사하게 $\operatorname{Min}$ 등(40)은 강황 첨가 두부에서 Hardness 분석 결과 일반 두부에 비하여 감 소하였다고 보고하였으며, Gumminess와 Brittleness의 경우

Table 1. Brix degree and color values of tofu added with red beet powder at different concentrations

\begin{tabular}{ccccc}
\hline \multirow{2}{*}{$\begin{array}{c}\text { Concentration of } \\
\text { red beet powder (\%) }\end{array}$} & \multirow{2}{*}{ Brix } & \multicolumn{3}{c}{ Color value } \\
\cline { 3 - 5 } & & $\mathrm{L}^{*}$ & $\mathrm{a}^{*}$ & $\mathrm{~b}^{*}$ \\
\hline 0 & $15.00 \pm 0.00^{\mathrm{e}}$ & $98.20 \pm 0.14^{\mathrm{a}}$ & $1.93 \pm 0.03^{\mathrm{e}}$ & $16.93 \pm 0.02^{\mathrm{a}}$ \\
0.5 & $15.33 \pm 0.01^{\mathrm{d}}$ & $61.37 \pm 0.02^{\mathrm{b}}$ & $2.20 \pm 0.03^{\mathrm{d}}$ & $14.80 \pm 0.04^{\mathrm{b}}$ \\
1.0 & $16.67 \pm 0.00^{\mathrm{c}}$ & $60.52 \pm 0.02^{\mathrm{c}}$ & $3.00 \pm 0.02^{\mathrm{c}}$ & $14.45 \pm 0.03^{\mathrm{c}}$ \\
1.5 & $17.00 \pm 0.00^{\mathrm{b}}$ & $57.86 \pm 0.01^{\mathrm{d}}$ & $4.64 \pm 0.02^{\mathrm{b}}$ & $13.56 \pm 0.03^{\mathrm{d}}$ \\
2.0 & $17.67 \pm 0.01^{\mathrm{a}}$ & $57.50 \pm 0.01^{\mathrm{e}}$ & $5.91 \pm 0.03^{\mathrm{a}}$ & $13.18 \pm 0.02^{\mathrm{e}}$ \\
\hline
\end{tabular}

${ }^{1)}$ Means \pm SD ( $\mathrm{n}=3$ ) in a row followed by same letter are not significantly different by Duncan's multiple rage test $(\mathrm{p}<0.05)$.

Table 2. Texture properties of tofu added with red beet at different concentrations

\begin{tabular}{cccccc}
\hline \multirow{2}{*}{ Properties } & \multicolumn{5}{c}{ Concentration of red beet powder $(\%)$} \\
\cline { 2 - 6 } & 0 & 0.5 & 1 & 1.5 & 2 \\
\hline Hardness $(\mathrm{g})$ & $500.34 \pm 60.20 \mathrm{a} \mathrm{l})$ & $540.04 \pm 20.50 \mathrm{a}$ & $530.33 \pm 30.21 \mathrm{a}$ & $406.32 \pm 15.21 \mathrm{~b}$ & $412.90 \pm 7.71 \mathrm{~b}$ \\
Cohesiveness & $0.52 \pm 0.05 \mathrm{a}$ & $0.53 \pm 0.03 \mathrm{a}$ & $0.52 \pm 0.04 \mathrm{a}$ & $0.53 \pm 0.03 \mathrm{a}$ & $0.54 \pm 0.02 \mathrm{a}$ \\
Springiness & $0.87 \pm 0.03 \mathrm{a}$ & $0.85 \pm 0.04 \mathrm{a}$ & $0.96 \pm 0.06 \mathrm{a}$ & $0.86 \pm 0.04 \mathrm{a}$ & $0.90 \pm 0.01 \mathrm{a}$ \\
Gumminess $(\mathrm{g})$ & $223.78 \pm 2.50 \mathrm{a}$ & $218.13 \pm 5.65 \mathrm{a}$ & $249.22 \pm 25.44 \mathrm{a}$ & $208.46 \pm 5.13 \mathrm{~b}$ & $204.98 \pm 4.61 \mathrm{c}$ \\
Chewiness $(\mathrm{g} \cdot \mathrm{mm})$ & $-5.20 \pm 0.04 \mathrm{a}$ & $-5.19 \pm 0.03 \mathrm{a}$ & $-5.19 \pm 0.03 \mathrm{a}$ & $-5.20 \pm 0.04 \mathrm{a}$ & $-5.20 \pm 0.04 \mathrm{a}$ \\
\hline
\end{tabular}

\footnotetext{
${ }^{1)}$ Means $\pm \mathrm{SD}(\mathrm{n}=5)$ in a row followed by same letter are not significantly different by Duncan's multiple rage test $(\mathrm{p}<0.05)$.
} 
강황농도가 증가될수록 감소하였으며 가장 높은 첨가구에 서 가장 낮은 값을 가지는 것으로 나타났다. Kim 등(41)은 인삼을 첨가한 건강 기능성 두부에서 인삼의 첨가량은 두부 의 조직특성 중 하나인 gumminess의 경우 인삼첨가 방법과 첨가량에 따른 통계적 유의성은 없는 것으로 나타났다.

\section{총 폴리페놀 함량 및 항산화 활성}

비트 분말 첨가량에 따른 두부의 총 폴리페놀 함량 및 항산화 활성은 $\mathrm{DPPH}$ 라디컬 소거능, $\mathrm{ABTS}$ 라디컬 소거능 및 FRAP을 통하여 알아보았고 측정한 결과는 Fig. 2에 나타 내었다. 먼저, 총페놀 함량의 경우 대조구는 $0.79 \mathrm{mg}$ $\mathrm{GAE} / \mathrm{kg}$ 으로 나타났고, 레드비트 분말 첨가량이 증가함에 따라 총 폴리페놀 함량이 증가하는 유의적으로 증가하는 것으로 나타났다. 폴리페놀물질은 식물체에 색깔을 부여하 고 식물성 식품의 고유한 맛에도 기여한다(42). 페놀성 물질 들은 hydroxyl $(-\mathrm{OH})$ 기를 가지고 있어 단백질 및 기타 거대

A

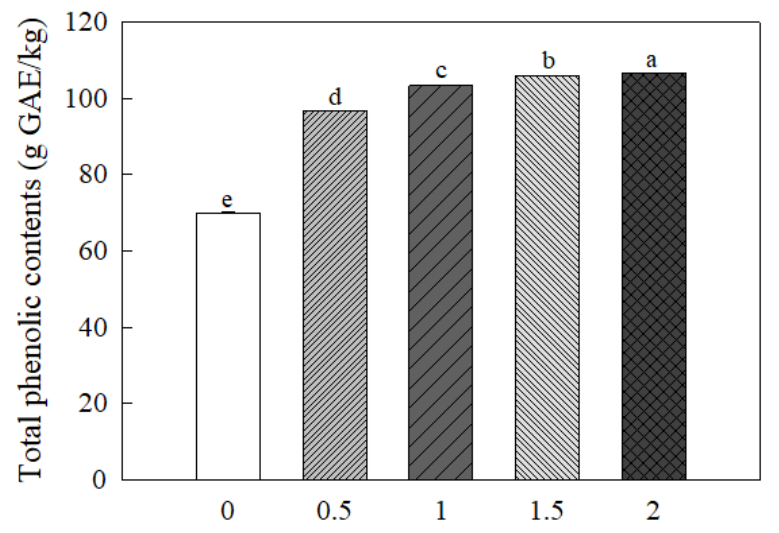

Concentration of red beet powder (\%)

B

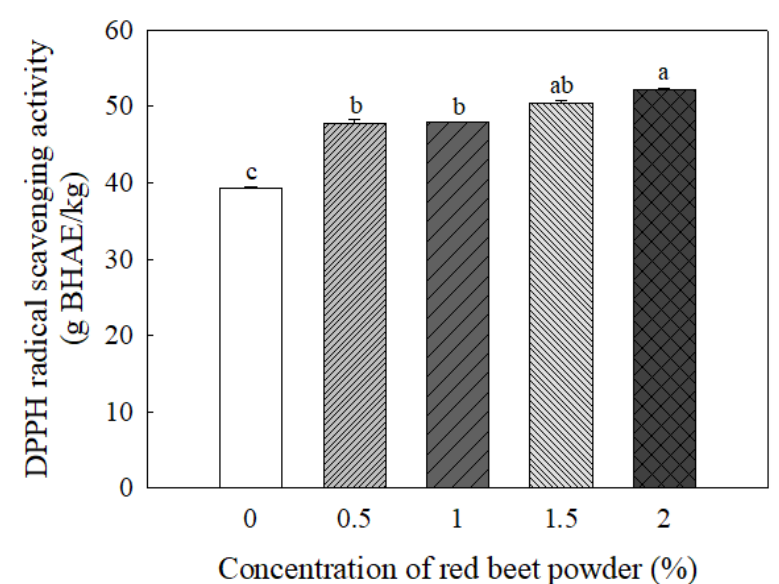

분자들과 결합하며, 특히 단백질과 결합하는 특성은 미생 물 세포와 작용하여 성장저해를 유발시켜 항산화, 항암 등 다양한 생리활성에 관여한다(43-45). DPPH 라디컬 소거능 의 경우 대조구의 경우 $3.93 \mathrm{~g} \mathrm{BHAE} / \mathrm{kg}$ 의 소거활성을 보였 고 $0.5 \%, 1 \%, 1.5 \%, 2 \%$ 첨가하였을 때, 각각 $4.78 \mathrm{~g}$ BHAE $/ \mathrm{kg}, 4.79 \mathrm{~g} \mathrm{BHAE} / \mathrm{kg}, 5.04 \mathrm{~g}$ BHAE $/ \mathrm{kg}, 5.22 \mathrm{~g}$ $\mathrm{BHAE} / \mathrm{kg}$ 로 로 유의적으로 증가하는 것을 알 수 있었다. $\mathrm{ABTS}$ 라디컬 소거능의 경우 대조구의 경우 $4.04 \mathrm{~g} \mathrm{AAE} / \mathrm{kg}$ 의 소거활성을 보였으며, $0.5 \%, 1 \%$ 첨가하였을 때, 각각 $4.84 \mathrm{~g} \mathrm{AAE} / \mathrm{kg}, 5.21 \mathrm{~g} \mathrm{AAE} / \mathrm{kg}$ 로 유의적으로 증가하였으며, $1-2 \%$ 첨가구에서는 유의적으로 차이가 없는 것으로 나타 났다. FRAP의 경우 대조군은 $7.44 \mathrm{~g} \mathrm{Fe}(\mathrm{II}) / \mathrm{kg}$ 였으며 레드 비트분말 첨가 농도가 증가함에 따라 유의적으로 증가하는 것으로 나타났다. 이러한 결과는 비트의 항산화 작용으로 부터 유래한 것으로 보이며, 레드비트의 Free radical 소거활 성능은 양파껍질, 흑미, 오디, 적양배추 결과와 일치하며,

C

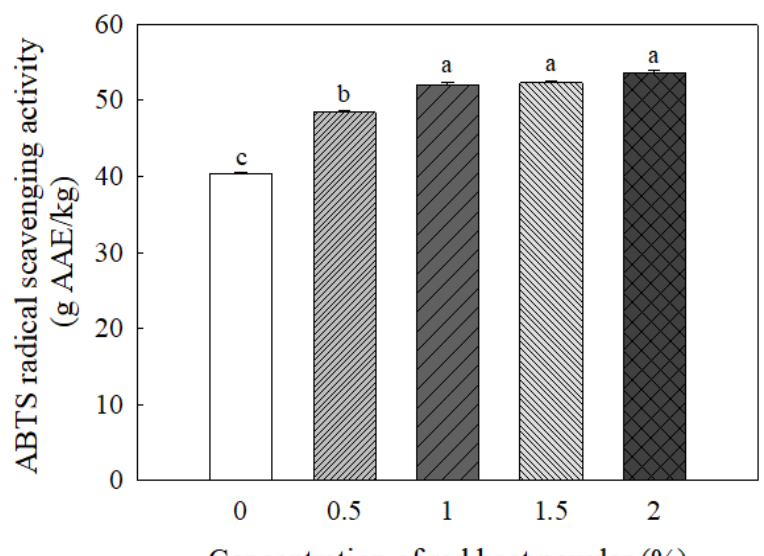

Concentration of red beet powder (\%)

D

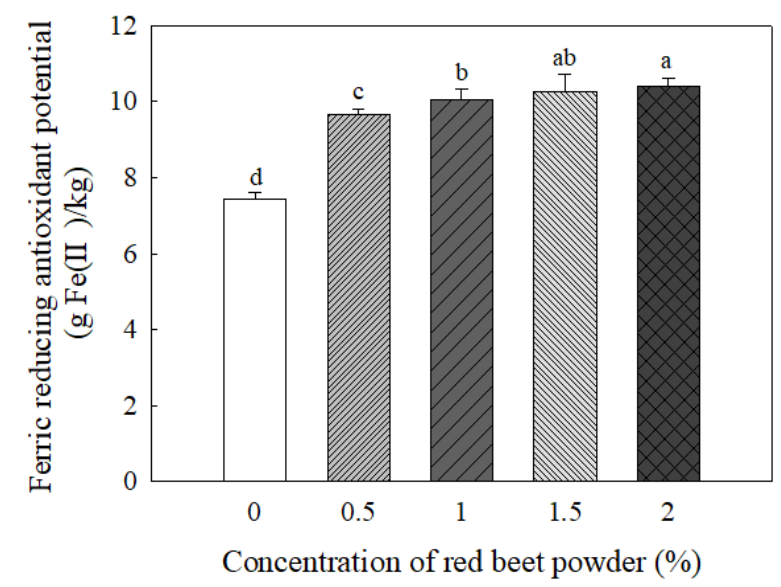

Fig. 2. Total phenolic contents and Antioxidant activity of tofu added with red beet powder at different concentrations. Different letters indicate significant differences by Duncan's multiple range test $(\mathrm{p}<0.05)$.

A, Total phenolic contents; B, DPPH radical scavenging activity; C, ABTS radical scavenging activity; D, FRAP (ferric reducing antioxidant power) assay. 
이러한 Phenol성 화합물은 $\mu$-electron system 주위의 운 elocalization에 의한 unpaired electron을 지원하고, 또한 aromatic hydroxyl group에서 활성 산소로 hydrogen원자를 쉽게 내어 줌으로써 항산화능을 나타내는 중요한 요인이다 (46). 또한, 식물유래 천연색소의 항산화활성(47)연구에서 일반적으로 천연물에 존재하는 생리활성물질은 대부분 화 합물로 항산화와 항균효과를 가지고 있는데, 이러한 천연 항산화 물질은 생체 내에서 활성산소로부터 생체를 보호하 는 작용을 함으로써 성인병 예방 및 항암, 항노화 기능을 수행한다.

\section{미생물 농도}

비트 분말 첨가량을 달리한 두부의 저장기간에 따른 일 반세균, 대장균군, 효모 및 곰팡이의 변화를 측정한 결과는 Fig. 3 와 같다. 대장균군 및 곰팡이는 모든시료에서 불검출

A

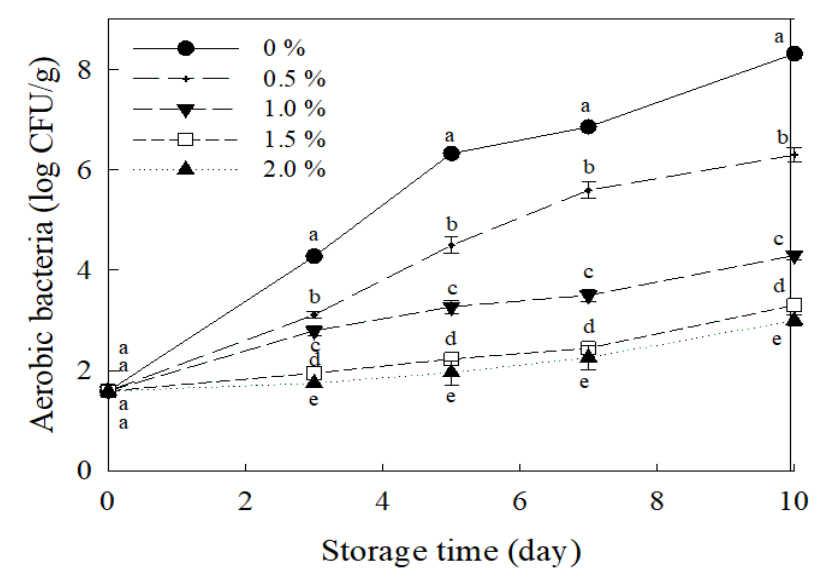

B

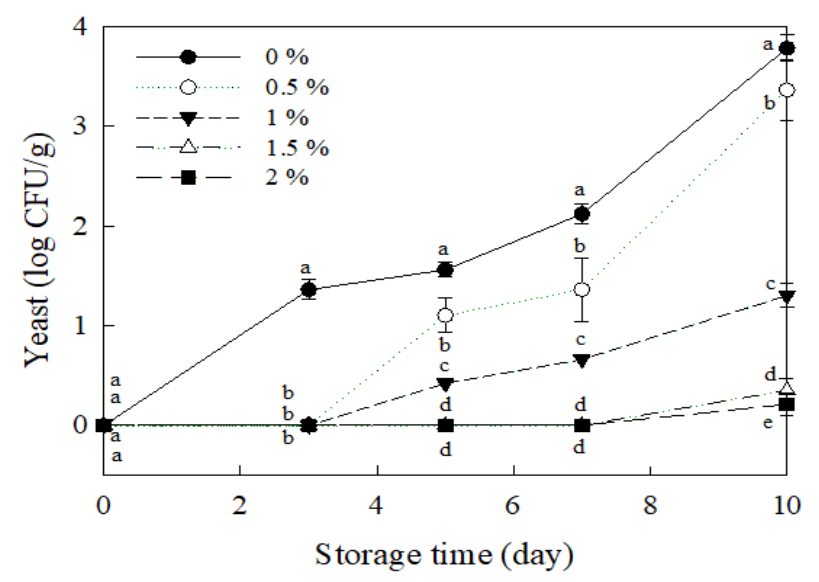

Fig. 3. The number of aerobic bacteria and yeast of tofu added with red beet powder at different concentrations. Different letters indicate significant differences by Duncan's multiple range test $(\mathrm{p}<0.05)$.

A, Aerobic bacteria $(\log \mathrm{CFU} / \mathrm{g})$; B, Yeast $(\log \mathrm{CFU} / \mathrm{g})$.
되었고, 일반세균의 경우 저장기간 0 일차 $1.60 \log \mathrm{CFU} / \mathrm{g}$ 수준이었으며, 대조구의 경우 저장기간이 지남에 따라 $1.60-8.32 \log \mathrm{CFU} / \mathrm{g}$ 의 범위로 급격하게 증가하는 것으로 나타났다. 레드비트분말 첨가구의 경우, 첨가량이 증가함 에 따라 감소하는 경향을 보였다. 즉, $0.5 \%$ 첨가구의 경우 $1.60-6.30 \log \mathrm{CFU} / \mathrm{g}, 1 \%$ 첨가구의 경우 $1.60-4.30 \mathrm{log}$ $\mathrm{CFU} / \mathrm{g}, 1.5 \%$ 첨가구의 경우 $1.60-4.30 \log \mathrm{CFU} / \mathrm{g}, 2 \%$ 첨가 구의 경우 $1.60-3.00 \log \mathrm{CFU} / \mathrm{g}$ 수준으로 점차 감소하는 것으로 나타났다. 효모의 경우 저장기간 0 일차 불검출이었 으며, 대조구의 경우 저장기간이 지남에 따라 0-3.80 log $\mathrm{CFU} / \mathrm{g}$ 범위로 급격히 증가하는 것으로 나타났다. 비트 분 말 첨가구의 경우 첨가량이 증가함에 따라 효모의 증식이 지연되는 것으로 나타났다. 즉, 저장기간 3 일차부터 $0.5 \%$ 첨가구의 경우 $1.10-2.22 \log \mathrm{CFU} / \mathrm{g}, 1 \%$ 첨가구의 경우 $0-1.30 \log \mathrm{CFU} / \mathrm{g}, 1.5 \%$ 첨가구의 경우 0-1.3 $\log \mathrm{CFU} / \mathrm{g}$, $2 \%$ 첨가구의 경우 0-0.35 $\log \mathrm{CFU} / \mathrm{g}$ 수준으로 대조구에 비해 급격히 저해되는 것으로 나타났다. 일반적으로 두부 의 경우 오염미생물이 두부의 단백질을 분해시켜 저분자량 의 peptide와 amino acid 및 amine 등 양성 전해질을 생성한 며, 총 세균 수가 107 이상이면 부패가 진행되는 것으로 간주한다(48). 본 연구에서 대조군 두부는 저장 5 일차에서 부패가 이미 시작되었고 레드비트 분말 첨가구의 경우 부패 가 억제된 것을 확인할 수 있었다.

\section{요 약}

비트 분말 첨가량을 달리하여 제조한 두부의 이·화학적 및 관능적 품질 특성을 조사하였다. 비트 분말의 첨가에 따른 두부의 수율은 유의적인 차이를 보이지 않았으며, 당 도는 비트분말의 첨가량이 증가할수록 증가하였다. 색도는 $\mathrm{L}$ 값 및 $\mathrm{b}$ 값은 감소하는 것으로 나타났으며, 조직감에서 hardness는 첨가량이 증가할수록 감소하였고, cohesiveness, springiness 및 chewiness의 경우 유의적으로 차이를 보이지 않았으며, gumminess는 감소하였다. 항산화 지표인 총 페놀 화합물 함량과 항산화 활성( $\mathrm{DPPH}, \mathrm{ABTS}$ 및 $\mathrm{FRAP})$ 은 비트 분말의 첨가량이 증가함에 따라 증가하는 경향을 보였다. 대조군의 총 세균수는 저장 기간 5 일차 이후 급격히 증가하 여 부패가 시작되었으며, 비트 분말이 첨가된 시료군의 총 세균수는 저장 기간 10 일차까지 낮게 유지되어 비트분말에 함유된 항균성 물질에 의해 세균의 증식이 억제된 것으로 판단된다. 따라서 두부의 품질을 유지하는 동시에 건강 기 능성 효과를 활용하기 위한 비트의 최적첨가량은 $1 \%$ 가 가장 적절한 것으로 판단된다. 


\section{References}

1. Lee DK (2002) Contribution of grape skin pigment and red beet pigment to the colour of cooked sausage. MS thesis. Dankook University, Korea, p 5

2. Kim SJ (2009) Change of the anti-oxidative activity and quality characteristics of Maejakgwa with coloring matter powder during the period of storage. MS thesis. Chungnam National University, Korea, p 1-11

3. Boo HO, Shin JS, Hwang SJ, Bae CS, Park SH (2012) Antimicrobial effects and antioxidative activities of the cosmetic composition having natural plant pigments. Korean J Plant Res, 25, 80-88

4. Seo EO, Ko SH (2014) Quality characteristics of muffins containing beet powder. Korean J Culinary Reasearch, 20, 27-37

5. Cho Y, Choi MY (2010) Quality characteristics of jelly containing added turmeric (curcuma longa L.) and Beet (Beta vulgaris L.). Korean J Food Cookery Sci, 26, 481-489

6. Jeong HJ, Lee HC, Chin KB (2010) Effect of red beet on quality and color stability of low-fat sausage during refrigerated storage. Korean J Food Sci Ani Resour, 30, 1014-1023

7. Constabel F, Nassif-Makki H (1971) Betalainbildung in beta-calluskulturen. Ber Dtsch Bot Ges, 84, 629-636

8. Von Elbe JH, Klement JT, Amundson CH, Cassens RG, Lindsay RC (1974) Evaluation of betalain pigments as sausage colorants. J Food Sci, 39, 128-132

9. Pasch JH, Von Elbe JH, Sell RJ (1975) Betalaines as colorants in dair products. J Milk Food Technol, 38, 25-28

10. Pavlov A, Kovatcheva P, Tuneva D, Ilieva M, Bley T (2005) Radical scavenging activity and stability of betalains from Beta vulgaris hairy root culture in simulated conditions of human gastrointestinal tract. Plant Foods Hum Nutr, 60, 43-47

11. Min JY, Park HY, Kim YS, Hong JS, Choi HD (2018) Antioxidant activity and stability of natural pigment extracted from red beetroot (Beta vulgaris L.). J Korean Soc Food Sci Nutr, 47, 725-732

12. Kim MH (2012) Antioxidant and antibacterial activity of extracts from Brassica juncea czerniak et coss., Celosia cristata L., Beta vulgaris L. Korean J Food Culture, 27, 719-729

13. Kim KT, Im JS, Kim SS (1996) A study of the physical and sensory characteristics of ginseng soybean curd prepared with various coagulants. Korean J Food Sci
Technol, 28, 965-969

14. Lee SJ, Chung ES, Park GS (2006) Quality chracteristics of tofu coagulated by apricot juice. Korean J Food Cookery Sci, 22, 825-831

15. Park KN, Park LY, Kim DG, Park GS, Lee SH (2007) Effect of Turmeric(Curcuma aromatica Salab) on shelf life of tofu. Korean J Food Preserv, 14, 136-141

16. Kwon SH (1972) Origin and importance of protein and oil of korean soybean. Korean J Food Sci Technol, 4, 158-161

17. Park YM, Cho HS, Park BH (2014) Quality characteristics of tofu prepared with Boehmeria nivea powder. J East Asian Soc Dietary Life, 24, 465-471

18. Lee JS, Kim GN, Jang HD (2008) Effect of red ginseong extract on storage and antioxidant activity of tofu. J Korean Soc Food Sci Nutr, 37, 1497-1506

19. Chun KH, Kim BY, Hahm YT (1999) Extension of tofu shelf-life with water soluble degraded chitosan as a coagulant. J Korean Soc Food Sci Nutr, 28, 161-166

20. Im JG, Park IK, Kim SD (2004) Quality characteristics of tofu added with basil water extracts. Korean J Soc Food Cookery Sci, 20, 144-150

21. Kang NS, Kim JH, Kim JK (2007) Quality characteristics of soybean curd mixed with freeze dried onion powder. Korean J Food Preserv, 14, 47-53

22. Chung DO (2010) Characteristics of tofu (soybean curd) quality mixed with Enteromorpha intenstinalis powder. J Korean Soc Food Sci Nutr, 39, 745-749

23. Kim MH, Shin MK, Hong GJ, Kim KS, Lee KA (2010) Quality assessment of soybean curd supplemented with saltwort (Salicornia herbacea L.). Korean J Food Cookery Sci, 26, 406-412

24. Hwang IG, Hwang Y, Kim HY, Lee J, Jeong HS, Yoo SM (2011) Quality characteristics of tofu (soybean curd) added with cheongyang hot pepper (Capscum Annuum L.) juice. J Korean Soc Food Sci Nutr, 40, 999-1005

25. Park BH, Kim M, Jeon ER (2013) Quality characteristics of Tofu added Ligularia fischeri powder. Korean J Food Culture, 28, 495-501

26. Lee KY, M Shafiur Rahman, Kim AN, Gul K, Kang SW, Chun J, Kerr WL, Choi SG (2019) Quality chracteristics and storage stability of low-fat tofu prepared with defatted soy flours treated by supercritical- $\mathrm{CO}_{2}$ and hexane. LWT, 100, 237-243

27. Yoo JY, Cho HS, Park BH (2013) Quality characteristics of tofu prepared with Lagocephalus lunaris powder. Korean J Food Preserv, 20, 495-501 
28. Singleton VL, Rossi JA (1965) Colorimetry of total phenolic with phosphomolybdic-phosphotungstic acid reagents. Am J Enol Vitic, 16, 144-158

29. Blois MA (1958) Antioxidant determination by the use of a stable free radical. Nature, 181, 1199-1200

30. Foroogh B, Abbas FMA, Azhar ME (2008) Antioxidant activity and phenolic content of various date palm (Phoenix dactylifera) fruits from Iran. Food Chem, 107, 1636-1641

31. Benzie IFF, Strain JJ (1996) The ferric reducing ability of plasma as a measure of "antioxidant power": the FRAP assay. Anal Biochem, 239, 70-76

32. Park YJ, Nam YL, Jeon BR, Oh NS, In MJ (2003) Effects of garlic addition on quality and storage characteristics of soybean curd (Tofu). J Korean Soc Agric Chem Biotechnol, 46, 329-332

33. Smith AK, Watanabe T, Nash AM (1960) Tofu from Japanese and United States soybeans. Food Technol, 14, 332-336.

34. Choi YO, Chung HS, Youn KS (2000) Effects of various concentrations of natural materials on the manufacturing of soybean curd. Korean J Postharvest Sci Technol, 7, 256-261

35. Park BH, Cho HS, Jeon ER, Kim SD, Koh KM (2009) Quality characteristics of soybean curd prepared with Lotus leaf powder. Korean J Food Culture, 24, 315-320

36. Song KY, O H, Zhang Y, Jeong KY, Kim YS (2016) Effects of beetroot (Beta vulgaris L.) powder on quality characteristics and retarding retrogradation by shelf-life of sponge cake. Korean J Food Cook Sci, 32, 696-703

37. Lee EJ, Ju HW (2016) Quality characteristics of bread added with beet powder. J East Asian Soc Dietary Life, 26, 55-62

38. Kim TY, Kim JM, Yoon IN, Chang CM (1994) Changes in chemical components of soybean cheese making from cow's milk added soybean curd. J Korean Soc Food Sci Nutr, 23, 837-844
39. Kim DH, Lim MS, Kim YO (1996) Effect of seaweeds addition on the physicochemical characteristics of soybean curd. J Korean Soc Food Nutr, 25, 249-254

40. Min YH, Kim JY, Park LY, Lee SH, Park GS (2007) Physicochemical quality chracteristics of tofu prepared with turmeric (Curcuma aromatic Salab). Korean J Food Cookery Sci, 23, 502-510

41. Kim KT, Im JS, Kim SS (1996) A study of the physical and sensory characteristics of ginseng soybean curd prepared with various coagulants. Korean J Food Sci Technol, 28, 965-969

42. Singleton VL (1981) Naturally occurring food toxicants; Phenolic substances of plant origin common in foods. Adv Food Res, 27, 149-242

43. Lee SO, Lee HJ, Yu MH, Im HK, Lee IS (2005) Total polyphenol contents and antioxidant activities of methanol extracts from vegetables propduced in Ullung Island. Korean J Food Sci Technol, 37, 233-240

44. Chen HY, Yen GC (2007) Antioxidant activity and free radical-scavenging capacity of extracts from guava (Psidium guava L.) leaves. Food Chem, 101, 686-694

45. Ko SH, Jeong HC (2018) Quality characteristics of redbeet powder and sulgidduk by redbeet powder of different ratios. Culi Sci \& Hos Res, 24, 13-21

46. Duthie G, Crozier A (2000) Plant-derived pheonoic antioxidants. Curr Opin Lipidol, 11, 43-47

47. Boo HO, Hwang SJ, Bae CS, Park SH, Song WS (2011) Antioxidant activity according to each kind of natural plant pigments. Korean J Plant Res, 24, 105-112

48. Jung GT, Ju IO, Choi JS, Hong JS (2000) Preparation and shelf-life of soybean curd coagulated by fruit juice of Schizandra chinensis ruprecht (Omija) and Prunus mume (maesil). Korean J Food Sci Technol, 32, 1087-1092 